\title{
INAUGURAL LECTURE: MR BULWARK AND THE PROTECTION OF HUMAN RIGHTS
}

\author{
Claudia Geiringer*
}

\section{To Erich - my first Mr Bulwark}

Let me begin with the question that I know is on all of your lips. Who (I hear you ask) is $\mathrm{Mr}$ Bulwark?

For the answer, I must refer you to my second year law students. Each year, it falls to me to introduce 300 of them to the contested concept of parliamentary sovereignty - that is, the idea that the courts will enforce any legislation that Parliament enacts, no matter how offensive or unwise that legislation may be. As part of that exercise, I dedicate one lecture to a debate on the advisability, or otherwise, of entrenching a supreme law bill of rights - this side of the room in favour; that side of the room against.

The particular year that I have in mind, my "great debate" had the misfortune to fall on the day before Professor David McLauchlan's contract law test. Now I'm told my students think I'm scary. But scariness is, after all, a relative thing. The day before Professor McLauchlan's contract law test, my classroom was eerily empty - my students were off cramming their brains full of "offer" and "acceptance". I soldiered on, facilitating the debate with the ragtag bunch of students in attendance. And in the next class, I provided a PowerPoint slide, summarising the main heads of argument that had been discussed in class and in the assigned readings. It looked something like this:

Chair in Public Law, Victoria University of Wellington School of Law; Director, New Zealand Centre for Public Law. Inaugural professorial lecture, delivered at Victoria University of Wellington on 29 April 2014. Minor changes have been made to the text as delivered, and light referencing has been added in order to acknowledge key influences. But I have attempted to retain the character of the piece as a public lecture. I am grateful to VUWLR for agreeing to publish it in this form.

Special thanks are due to Sir Geoffrey Palmer and Sir Kenneth Keith for their inspiration, their wisdom and their tolerance. 


\title{
The Bill of Rights debate - summary of main arguments
}

\author{
Affirmative \\ - Lack of controls on \\ government \\ - Bulwark against erosion \\ of rights \\ - Better to act before the \\ crisis \\ - Protection of minorities \\ - Educative function \\ - Compliance with \\ international law
}

Negative

- Anti-democratic - giving power to unelected, unaccountable and unrepresentative judiciary

- Uncertainty and unpredictability of law

- Freezes constitutional developments

- Rights sufficiently protected under current law

For our purposes, the point of interest is the second bullet point in the left hand column. It refers to an argument that, in New Zealand at least, the danger is not that our rights will be abruptly swept away but that they may be gradually eroded so that, like the frog in the pot of boiling water, ${ }^{1}$ we fail to detect the moment when the temperature is no longer conducive to our well-being. An entrenched bill of rights, so the argument goes, provides a bulwark (that is to say, a "fortification" or "seawall") $)^{2}$ to protect against this process of erosion.

This particular year, when it came time for the terms test, I asked my students to advise a fictional Minister Plimmer on a number of questions, one of which was the desirability of entrenching a supreme law bill of rights. Here is a (verbatim) excerpt from one of the answers I received:

Dear Minister Plimmer

I am writing to advise you on the arguments for and against entrenching a supreme law Charter of Human Rights Act.

To entrench a Charter of Human Rights will clearly protect fundamental human rights and safeguard them for future generations. Bulwark's academic commentary on the erosion of rights supports this view as he argues that over time, fundamental rights are likely to be chipped away at and gradually disappear. Thus we should act now in a moment of calm rather than reach a possible future situation where Bulwark's erosion of rights argument has occurred.

1 My brother Felix tells me that this apocryphal tale is based on the work of German physiologist Friedrich Goltz - the missing detail being that the frog had been lobotomised.

2 Oxford English Dictionary Online (Oxford University Press, June 2014) "bulwark, n". 
Here is another:

Many Pro-entrenchment parties have taken Bulwark's idea of "erosion of rights" - that although some

legislation does not fully erode human rights, if we allow some erosion, it can lead to other erosions.

And a third:

Bulwark refers to the current BoR as slowly eroding rights of citizens, but as it is gradual we do not realize the extent of this occurring.

I could go on but you get the idea. For my students (well, some of them), the legal pantheon Chitty On Contracts, for example, and Arlidge, Eady and Smith On Contempt - had been joined by a new deity: Bulwark Against Erosion.

This incident happened some years ago. But in the years that followed, I found myself growing strangely attached to Mr Bulwark, who I pictured not - as my students did - as a stuffy academic cloistered in his ivory tower, but as a lone figure, hunched against the cold, his finger stalwartly plugging the hole in the dike through which the water had begun to seep.

And when I sat down (in preparation for this lecture) to think hard about my image of $\mathrm{Mr}$ Bulwark, I was struck by a couple of other things too. The first was how concrete my image of $\mathrm{Mr}$ Bulwark seemed to be. The second was the reason for this. It came to me that this Mr Bulwark that inhabited my imagination was not entirely a creation of my imagination. That is to say, like any scholar worth her salt, I had drawn somewhat freely on the primary source material in creating him. This Mr Bulwark of mine is a tall imposing figure, with grey hair, aquiline features and a resolute brow. In character, he's a man who likes to be a-fixing. And he sees many, many things around him that, indeed, need to be fixed. He's a generous person who tries to be gentle with the younger generation. But his restless impatience with our maddening cautiousness does have something of a tendency to leak through at the edges.

$\mathrm{He}$ is, of course, Sir Geoffrey Palmer - former professor of law at this University (as well as one or two other things besides) and the political sponsor of the New Zealand Bill of Rights Act. His (real world) advice to me for this lecture was: "Don't be too moderate!"

So now that I'd worked out who my Mr Bulwark was, the picture started to shift around him. When I looked again, Mr Bulwark had removed his finger, and expertly plugged the hole in the dike with fresh cement. And I saw, too, that I'd been mistaken in thinking he was alone. Another man shorter but also greying - was mixing the cement in a wheelbarrow, and the two of them were securing new bricks in place along the top of the sea wall. No prizes for guessing. This was the other "Sir" - Sir Kenneth Keith - another former Victoria University of Wellington professor of law and the man who was Sir Geoffrey's partner in crime for so many of the constitutional innovations of the Fourth Labour Government. Between the two of them, they're responsible for countless of the bricks 
in this constitutional sea wall of mine - a new Constitution Act here, a select committee system there, an Official Information Act laid out beside it, a new electoral system thrown in for good measure. And so on and so forth.

But for Sir Geoffrey at least, the sea wall is still neither as high enough nor as strong enough as he would wish. And as well, there's one brick in the wall that especially rankles. He had wanted to fashion it from the strongest clay. But, instead, he was made to work with a spongy, porous substance that holds liquid up to a point but then, under pressure, gives way, so that the water seeps through to the other side. This brick-of-sponge is the New Zealand Bill of Rights Act 1990 (the Bill of Rights) - a document born from compromise and thwarted ambition. In 1984, the new Minister of Justice Geoffrey Palmer appointed a committee of experts (including his friend and former colleague Ken Keith) to draft a bill of rights for New Zealand and accompanying discussion document. ${ }^{3}$ The White Paper that resulted made the case for an entrenched, supreme law bill of rights. ${ }^{4}$ But when the public was consulted, the proposal failed to attract anything like the level of support required for such a significant constitutional departure. This tolled the death knell for the White Paper proposal. But rather than abandon the initiative altogether, Palmer arranged for the document to be redrafted and, ultimately, enacted as an "ordinary statute" - in other words, a law that is not entrenched (it could be repealed or amended by a simple majority in the House of Representatives) and that is not supreme (it cannot be used by judges to strike down or render invalid or ineffective contrary legislation).

The main ways in which this "ordinary law" bill of rights impacts on the operations of government are well known to lawyers. But out of deference to others, let me rehearse them briefly. First, the Bill of Rights is stated to "apply" to the acts of the legislative, executive and judicial branches of government, as well as to others who exercise public functions conferred or imposed by law. ${ }^{5}$ This means that in the absence of a specific legislative mandate to the contrary, government officials are supposed to act consistently with the Bill of Rights.

Secondly, the Bill of Rights requires that wherever laws "can" be interpreted in a way that is "consistent" with human rights, they must be so interpreted. ${ }^{6}$ So, to the extent a law is capable of bearing more than one meaning, it must be given a meaning that is Bill of Rights-consistent.

3 Other members of the group included senior justice official BJ Cameron and barrister DAR Williams. New Zealander and expert in Canadian constitutional law Professor Peter Hogg was also brought into the discussions. For an evocative account of the deliberations, see KJ Keith "The New Zealand Bill of Rights Act 1990 - An Account of Its Preparation" (2013) 11 NZJPIL 1.

4 Department of Justice A Bill of Rights for New Zealand: A White Paper (1985) [A White Paper].

5 New Zealand Bill of Rights Act 1990, s 3.

6 New Zealand Bill of Rights Act 1990, s 6. 
Thirdly, the Bill of Rights requires the Attorney-General to table a report in the House of Representatives whenever he or she believes that a new Bill introduced to the House is inconsistent with the rights and freedoms protected by the Bill of Rights. ${ }^{7}$ This does not prevent inconsistent laws from being passed. But it is supposed to place a spotlight on human rights issues - both during the legislative process and also internally within government when legislation is being developed.

Ultimately, though, the key difference between our Bill of Rights and the (more common or garden) supreme law kind is that our Bill of Rights cannot be used to countermand or contradict a clear legislative direction, even if that direction results in inconsistency with fundamental rights. For my Mr Bulwark - that is to say, for Sir Geoffrey - this has never ceased to be a subject of disappointment and regret, and he has continued to advocate for more comprehensive reform. ${ }^{8}$

But scholars in the generation to follow have been somewhat more circumspect. I feel I must acknowledge here my colleague Dr Petra Butler and her husband and collaborator, Dr Andrew Butler. They have criticised the New Zealand bill of rights model on a number of occasions and proposed significant reform, modelled on the Canadian Charter of Rights and Freedoms. ${ }^{9}$ But it's fair to say, they have bucked the trend in this regard. Most scholars in what I am loosely calling "the Next Generation" - and I'm thinking here of the likes of Rishworth, McLean, Geddis and Geiringer - have been slow to embrace further significant reform of the kind imagined in the 1980s White Paper. Their (our) offerings on the question have ranged from conspicuous silence to frank scepticism. ${ }^{10}$

I believe I fall into the former camp. ${ }^{11}$ I have deliberately refrained from expressing a view on the supremacy question. But like others of my generation, what has piqued my intellectual curiosity is the potential of the statutory bill of rights model to provide an alternative vision of

$7 \quad$ New Zealand Bill of Rights Act 1990, s 7.

8 Most recently Geoffrey Palmer "The Bill of Rights after Twenty-One Years: The New Zealand Constitutional Caravan Moves on?" (2013) 11 NZJPIL 257 at 284-288; and Geoffrey Palmer Reform: A Memoir (Victoria University Press, Wellington, 2013) at 729-733.

9 For example Andrew S Butler "Strengthening the Bill of Rights" (2000) 31 VUWLR 129; and Andrew Butler and Petra Butler "Protecting Rights" in Caroline Morris, Jonathan Boston and Petra Butler (eds) Reconstituting the Constitution (Springer, Heidelberg, 2011) 257.

10 For example Janet McLean "Legislative Invalidation, Human Rights Protection and s 4 of the New Zealand Bill of Rights Act" [2001] NZ Law Review 421; and Paul Rishworth "Human Rights and the Reconstruction of the Moral High Ground" in Rick Bigwood (ed) Public Interest Litigation (LexisNexis, Wellington, 2006) 115 .

11 Andrew Geddis is probably also best located in this camp. Though see Andrew Geddis "Prisoner Voting and Rights Deliberation: How New Zealand's Parliament Failed" [2011] NZ L Rev 443 at 474 (expressing apparent support for the retention of parliamentary sovereignty but urging Parliament to do better if it wishes to retain his allegiance). 
constitutionalism - one that moderates between the extremes of judicial and parliamentary supremacy. It is to assessing that potential that I've tried to direct my academic energy. ${ }^{12}$

For my Mr Bulwark, this lack of scholarly support for a supreme law bill of rights reflects a failure of courage and imagination. But as he freely admits, Sir Geoffrey was not always such an ardent supporter of supreme law bills of rights. In 1968, the new Victoria University political science lecturer wrote an erudite essay opposing the introduction of a New Zealand bill of rights. ${ }^{13}$ And Sir Kenneth began his scholarly life, too, as a bill of rights sceptic. ${ }^{14}$ And despite his eventual support for the 1980s proposal for a supreme law bill of rights, Sir Kenneth's more recent writings suggest that he is now largely reconciled to the constitutional compromise reflected in the New Zealand Act. ${ }^{15}$

I do not mention these changes of heart by way of criticism; far from it. As Sir Kenneth once said in his own defence (quoting Emerson): "A foolish consistency is the hobgoblin of little minds." ${ }^{16}$ But the fact that these two deep thinkers have vacillated over time in their support for a supreme law bill of rights suggests at least that the question is one of some difficulty. And it suggests, too, that the answer might be a contingent one that depends on a range of highly contextspecific circumstances.

Against that background, in the first part of this lecture, I want to defend the circumspection shown by my generation on the supremacy question. I'll suggest that for Keith and Palmer, both their initial scepticism towards constitutionalised bills of rights, and their subsequent conversions, were rational and thoughtful responses to a range of influencing factors - some of them global and some local in origin.

12 For example Claudia Geiringer "The Dead Hand of the Bill of Rights? Is the New Zealand Bill of Rights Act 1990 a Substantive Legal Constraint on Parliament's Power to Legislate?" (2007) 11 Otago LR 389; Claudia Geiringer "The Principle of Legality and the Bill of Rights Act: A Critical Examination of $R v$ Hansen" (2008) 6 NZJPIL 59; Claudia Geiringer "On a Road to Nowhere: Implied Declarations of Inconsistency and the New Zealand Bill of Rights Act" (2009) 40 VUWLR 613; and Claudia Geiringer "Sources of Resistance to Proportionality Review under the New Zealand Bill of Rights Act" (2013) 11 NZJPIL 123.

13 GWR Palmer "A Bill of Rights for New Zealand?" in KJ Keith (ed) Essays on Human Rights (Sweet \& Maxwell, Wellington, 1968) 106.

14 See "Evidence Presented to the Constitutional Reform Committee 1964 on the New Zealand Bill of Rights" [1965] III AJHR I14 at 29 (submission of DL Mathieson and KJ Keith), reprinted in L Cleveland and AD Robinson (eds) Readings in New Zealand Government (Reed Education, Wellington, 1972) 207.

15 Keith, above n 3.

16 KJ Keith "A Bill of Rights for New Zealand? Judicial Review versus Democracy" (1985) 11 NZULR 307 at 307, quoting Ralph Waldo Emerson's 1841 essay "Self-Reliance". Sir Kenneth in fact observes that he was "tempted" to quote Emerson in this regard until he remembered another of Emerson's quotes: "I hate quotations". 
I'll then suggest that the experience of my generation has been both totally different and completely the same. We, too, have responded to a similar set of (external and domestic) stimuli. But the constitutional moment - both domestically and globally - has been a different one. Perhaps most especially, the constitutional reforms spearheaded by Keith and Palmer themselves have made it necessary to engage in a different kind of scholarship - scholarship aimed at exploring and understanding the new constitutional environment rather than at precipitating further significant change.

In the second part of this lecture, though, I'll concede that this excuse is wearing a little thin. Significant though they were, the constitutional reforms of the 1980s and early 1990s have had ample time to bed down now. And so we're in a position to start reaching some definitive conclusions about how well they have worked. And I then want to draw on some of my own research on the Bill of Rights (as well as on that of others) to suggest that it is an instrument that has never quite grown into its skin: that it has not had the transformative effect that some, over the years, have hoped or claimed for it; and that its constraining impact has not been reinforced as strongly as we might have hoped by the introduction of a proportionality-based electoral system.

I will conclude by suggesting that it's time to move back into reform mode; that we need to start listening again to the Mr Bulwarks in our midst.

\section{PLUS ÇA CHANGE}

I begin then with my attempt to contrast the intellectual journeys of my own, and the Keith/Palmer generation. There is a danger that, in comparing my own intellectual journey with that of these two extraordinary men, I may be seen to be engaging in an act of self-aggrandisement. But an inaugural lecture is an occasion to celebrate the scholarly tradition of one's institution, as well as to locate oneself within it. So I hope that my remarks may be taken in that light and, as well, as an acknowledgement of the debt that my generation owes to those who have come before.

I hope, too, that my two "Sirs" will forgive the omissions and over-simplifications that are about to follow but in my limited time, there are a few matters that I particularly want to emphasise. The first is the influence on both of them of post-graduate study in the United States - Sir Kenneth at Harvard in 1964; and Sir Geoffrey two years later at Chicago. For both, this was a formative experience and the beginning of a long association with the American academy.

Now it might be tempting to think that this exposure at such a critical stage to one of the oldest and most powerful supreme law constitutions in the world would necessarily dispose one favourably towards that mode of constitutionalism. But this would be to underestimate the American legal academy. The strength of the United States tradition of supreme law constitutionalism is nothing if not matched by the outpouring of sceptical literature that it has generated.

It may be helpful at this point, again for those outside the discipline, to explain the most common objection that is made to supreme law constitutions - what is sometimes called the 
"counter-majoritarian difficulty". ${ }^{17}$ The core of this objection is that, by conferring on judges the power to override legislation, supreme law constitutions are giving an elite, unelected group of legal technocrats the power to veto democratic decision making. This concern is lent potency by the fact that constitutions tend to be drafted in broad, flexible language - language that is capable of speaking down through the ages but that, by the same token, leaves a great deal to the judicial imagination in its application to particular fact situations. In the specific context of a bill of rights, this problem of indeterminacy is amplified by the fact that few rights are absolute. Most of us would accept, for example, that the right to freedom of expression doesn't extend to exposing small children to pornography or to imperiling the fairness of a criminal trial. A supreme law bill of rights removes from our democratic institutions and gives to judges (themselves acting by simple majority vote) the ultimate power to decide how and when these kinds of trade-offs can be made.

That in a nutshell is the "counter-majoritarian difficulty" - a problem that has been described as "the central obsession of modern constitutional scholarship" in the United States. ${ }^{18}$ And there is something else that it's important to understand. In New Zealand we tend to assume (at least in popular discourse) that support for judicially-enforced bills of rights is a progressive position. But in the United States, the counter-majoritarian difficulty is, if anything, a preoccupation of left-leaning scholars. And this makes sense if you think about the history. In New Zealand, we most readily associate the work of the United States Supreme Court with the era of the Warren Court during the 1950s and 1960s when the Court made important social justice interventions, for example, to compel racial desegregation (think Brown v Board of Education), ${ }^{19}$ to strengthen criminal process protections (think Miranda $v$ Arizona), ${ }^{20}$ to protect political speech ${ }^{21}$ and to require the reapportionment of gerrymandered electoral districts. ${ }^{22}$ And this was, of course, the fertile period during which my "two Sirs" were studying in the United States.

But we need to remember that this is possibly the only period in history when the United States Supreme Court has been of a progressive cast. And for that reason, the judicial activism of the

17 The phrase was coined by Alexander Bickel The Least Dangerous Branch: The Supreme Court at the Bar of Politics (Bobbs-Merrill, Indianapolis, 1962). The literature on the counter-majoritarian difficulty is vast. For three relatively recent contributions by United States-based scholars, see Jeremy Waldron "The Core of the Case Against Judicial Review" (2006) 115 Yale LJ 1346; Richard H Fallon Jr "The Core of an Uneasy Case for Judicial Review" (2008) 121 Harv L Rev 1693; and Mark Tushnet "How Different are Waldron's and Fallon's Core Cases For and Against Judicial Review?" (2010) Oxford J Legal Studies 49.

18 Barry Friedman "The History of the Countermajoritarian Difficulty, Part One: The Road to Judicial Supremacy" (1998) 73 NYU L Rev 333 at 334.

19 Brown v Board of Education 347 US 483 (1954).

20 Miranda v Arizona 384 US 436 (1966).

21 For example New York Times v Sullivan 376 US 254 (1964); and NAACP v Button 371 US 415 (1963).

22 For example Baker v Carr 369 US 186 (1962); and Wesberry v Sanders 376 US 1 (1964). 
Warren Court actually caused left-leaning scholars of the period considerable unease. ${ }^{23}$ They thought back, for example, to the Lochner era $^{24}$ - a period around the turn of that century when an activist but not-so-progressive Court had discovered economic rights, such as freedom of contract, in the indeterminate language of the Constitution and had used them to strike down progressive labour laws (seeking, for example, to regulate child labour or to specify maximum working hours). ${ }^{25}$ During this earlier period the progressive academy had become sceptics of judicial activism, so that in the 1950s and 1960s, left-leaning scholars found themselves on the horns of a dilemma: how to remain true to their principles despite liking the results achieved by the Warren Court? Some resolved this dilemma by becoming determined critics of the Warren Court. But others became preoccupied with finding a way out of the counter-majoritarian difficulty - on developing a normative theory of judicial review that would justify the exercise of a judicial veto on majoritarian decision making in some circumstances.

It seems clear that during his year at Chicago, Sir Geoffrey was particularly exposed to the former type of scholarship. He took classes, for example, with Philip Kurland - a leading critic of the Warren Court. ${ }^{26}$ And it was soon after his return from Chicago that he expressed his own opposition to a New Zealand bill of rights. ${ }^{27}$ Sir Kenneth, on the other hand, had recorded his opposition to a bill of rights the year before he went to Harvard to complete an LLM. ${ }^{28}$ And he, too, must have been exposed at Harvard to the sceptical position (of which, Harvard academics were the leading exponents). But it was during this period that he also first learnt of the other type of scholarship - scholarship that sought to theorise its way out of the counter-majoritarian difficulty. Specifically, he was introduced to "process theory", which promised a way to distinguish the (arguably undesirable) interventions of the Lochner era with the (arguably desirable) interventions of the Warren Court. ${ }^{29}$

23 I draw in this paragraph most directly on Barry Freidman's magisterial five-part series on the history of the counter-majoritarian difficulty and, especially: Barry Friedman "The Birth of an Academic Obsession: The History of the Countermajoritarian Difficulty, Part Five" (2002) 112 Yale LJ 153.

24 Named after one of the archetypal cases of the era: Lochner v New York 198 US 45 (1905).

25 Though see Barry Friedman "The History of the Countermajoritarian Difficulty, Part Three: The Lesson of Lochner" (2001) 76 NYU L Rev 1383 (discussing revisionist scholarship which seeks to rehabilitate the Lochner Court by locating its decisions in existing precedent).

26 See Palmer Reform, above n 8, at ch 6; Philip B Kurland Politics, the Constitution and the Warren Court (University of Chicago Press, Chicago, 1970).

27 Palmer, above n 13.

28 "Evidence Presented to the Constitutional Reform Committee 1964 on the New Zealand Bill of Rights", above $\mathrm{n} 14$.

29 See especially Keith, above n 3, at 5-7. 
Although it had its roots in the 1930s, "process theory" reached its apogee in 1980, in John Hart Ely's Democracy and Distrust - a book which had a profound impact on the drafters of the New Zealand Bill of Rights. ${ }^{30}$ Ely suggested (as others had done) that the judicial activism of the Warren Court reflected an unwritten 1930s constitutional settlement, in which the Supreme Court claimed for itself the right to enforce aggressively some aspects of the Constitution but left others to be controlled by Congress. And Ely saw in this settlement a basis for a theory of constitutional legitimacy that could overcome the counter-majoritarian difficulty. The key for him was that courts should confine their attention primarily to protecting the "processes" of government - by which he meant both the particular processes of public decision making (supported, for example, by criminal procedure rights in the Constitution) and, more broadly, the proper functioning of the democratic process (supported, for example, by the freedoms of political expression and association). And the courts should also intervene, he said, to protect the position of minority groups whose interests are inherently vulnerable to majoritarian decision making. If confined in this way judicial enforcement of a Constitution is not anti-democratic, he said, but in fact, democracy-reinforcing.

So then the Palmer/Keith conversion to the case for a supreme law bill of rights unfolded against the background of the landmark social justice achievements of the Warren Court, and was galvanised by the emergence of a theory of judicial review that enabled admirers of those achievements to distance themselves from the less progressive judicial interventions of an earlier era. The drafters of the 1980s White Paper saw in process theory a blueprint for constitutional design. ${ }^{31}$ By orienting their draft bill of rights around so-called process rights, and omitting much of the indeterminate language that had tempted United States judges of an earlier era into more substantive policy-based interventions, they believed they could take the best and discard the worst of American constitutionalism.

At the risk of incurring Sir Kenneth's wroth, I propose to skip over significant international law developments during this period, and to move to influences closer to home. ${ }^{32}$ This is a well-known story, so let me tell it briefly. In his 1968 refutation of the case for a supreme law bill of rights, the young Geoffrey Palmer painted an image of New Zealand as a small, homogenous society with a correspondingly consensus-based political culture - a society, he said, that was more concerned with

30 John Hart Ely Democracy and Distrust: A Theory of Judicial Review (Harvard University Press, Cambridge (Mass), 1980).

31 See especially A White Paper, above n 4, at [4.14]-[4.16]; Keith, above n 16; Keith, above n 3; and Geoffrey Palmer "Human Rights: The Proposed New Zealand Bill of Rights" [1998] The Parliamentarian 10 at 11 .

32 On the significance of these developments for the White Paper proposal, see for example A White Paper, above n 4, at [3.4], [4.21]-[4.23] and [4.26]; Keith, above n 3, at 7-8; Palmer, above n 31, at 13. 
butterfat and wool prices than with civil liberties. ${ }^{33}$ By the late 1970 s, this picture had been shattered. Increased immigration, Māori urbanisation, and the counter-culture and protest movements of the 1960s and 1970s had served to make New Zealand society both empirically more diverse, and far more conscious of the fault lines that divided it. These factors combined in the 1970s and early 1980s with economic recession, galloping inflation, and an authoritarian prime minister with a predilection for trampling over constitutional niceties, to expose the thinness of New Zealand's constitutional arrangements. ${ }^{34}$

By this I mean far more than the absence of a supreme law bill of rights. One of the great insights of the founders of the United States Constitution was that structural constraints on the power of the State can be just as, if not more, effective than substantive ones. They put their primary faith, not in a bill of rights (which was, at best, an afterthought) but in an elaborate system of structural checks and balances through which the power of the State was to be shared out between different institutions. "Ambition", as James Madison famously put it, "must be made to counteract ambition". 35

But New Zealand lacked (and lacks) many of these structural techniques for dividing power. We have a highly centralised political system, with no federal division of powers, no upper House and no strict separation between our legislative and executive branches. Political power is concentrated in the House of Representatives which, at least prior to the introduction of a proportionality-based voting system, was itself dominated by Cabinet. The First Past the Post electoral system created a strong bias towards single-party majority governments in which one party wields an absolute majority on the floor of the House. And this executive dominance of Parliament was fortified by strong party discipline, making it rare (as it still is) for New Zealand members of Parliament (MPs) to vote against their party. This combination of factors famously led one Australian commentator to describe New Zealand under First Past the Post as an "executive paradise". ${ }^{36}$

All of this is well known. It's relevance to the story that I'm trying to tell is simply this. Keith and Palmer's conversion to the case for a supreme law bill of rights arose out of their overall assessment of the state of New Zealand's constitution - the absence of explicit protections of civil

33 Palmer, above n 13, at 127 and 130.

34 Michael King The Penguin History of New Zealand (Penguin Books, Auckland, 2003) at chs 25-29; Hugh Templeton All Honourable Men: Inside the Muldoon Cabinet 1975-1984 (Auckland University Press, Auckland, 1995); Palmer Reform, above n 8, at 348.

35 Alexander Hamilton, James Madison and John Jay The Federalist Papers (Oxford University Press, Oxford, 2008) no 51 (Madison).

36 Leslie Zines Constitutional Change in the Commonwealth (Cambridge University Press, Cambridge, 1991) at 47 . 
liberties being only one of a range of interrelated factors that concerned them. ${ }^{37}$ To invoke Sir Kenneth again (this time himself quoting Matthew Arnold), they: "saw life steadily and saw it whole". 38

This lecture is already drowning in metaphor but there's more to come. Another professor of law at Victoria University of Wellington, the late great Quentin Quentin-Baxter, once famously described a constitution as a "human habitation". 39 "Like a city", he said: ${ }^{40}$

... it may preserve its life and beauty through centuries of change. It may, on the other hand, become

either a glorious ruin from which life has departed, or a dilapidated slum that no longer knows the great

tradition of its builders.

It's difficult to improve on this image, but that has not stopped others from trying. Sir Geoffrey coined the idea of a "constitutional caravan", that is to say, a "human habitation" on wheels. ${ }^{41}$ His son Matthew, former Dean of the Law School and one of my predecessors as Director of the New Zealand Centre for Public Law, likened the New Zealand constitution to the unkempt natural landscape, growing up from the foundation - the whenua - of the Treaty of Waitangi. ${ }^{42}$

My Mr Bulwark led me first to a sea-wall - an image, one might say, for the age of climate change. But I find myself compelled to confess that what really comes to mind for me when I think about the New Zealand constitution is something far more prosaic. It's one of those never-ending soups that my father Erich used to make - the sort that sit in the crockpot day after day, being topped up by a handful of this and that from the vegetable drawer.

Here are the characteristics of this constitutional soup that I have in mind. The first is that it's not quite like any other soup that has come before. It's inspired, certainly, by other soups. And some of the ingredients are even imported. But there's an aspect of terroir about this soup; even the imported ingredients taste differently when mixed with the New Zealand water.

37 See for example A White Paper, above n 4, at [4.2]-[4.3] and [4.7]; Geoffrey Palmer Unbridled Power? An Interpretation of New Zealand's Constitution and Government (Oxford University Press, Wellington, 1979); Palmer Reform, above n 8, at ch 11; Keith, above n 3, at 8 .

38 KJ Keith "Public Law in New Zealand" (2003) 1 NZJPIL 3 at 3, citing Matthew Arnold's 1849 sonnet "To a Friend". See also "Foreword" in Claudia Geiringer and Dean F Knight (eds) Seeing the World Whole: Essays in Honour of Sir Kenneth Keith (Victoria University Press, Wellington, 2008) at xi.

39 RQ Quentin-Baxter "The Governor-General's constitutional discretions: an essay towards a re-definition" (1980) 10 VUWLR 289 at 290.

40 At 290.

41 Palmer "The Bill of Rights after Twenty-One Years", above n 8, at 258.

42 Matthew Palmer The Treaty of Waitangi in New Zealand's Law and Constitution (Victoria University Press, Wellington, 2008) at 5. 
Secondly, there is no recipe. It's a pragmatic soup that is constructed from day to day from the ingredients that happen to be at hand. It has, as Professor Quentin-Baxter also said, "as much capacity for growth and change as does the human body between birth and dying". 43

But thirdly - and this is important - even if the exact ingredients do not matter it's still crucial to get the balance of flavours right; the mix between the salty, the sweet, the sour, the bitter and the umami. Salt is a wonderful thing, but too much salt spoils the broth. A constitution, like a soup, is all about balance - the balance between centralisation and diffusion; constraint and efficiency; pragmatism and principle; between constitutional safeguards and majoritarian control.

Fourthly and finally, for all the reasons just given, it's crucial to taste the soup; to use one's senses to check the flavour hasn't tipped too far one way or the other. Constitutional theorising simply cannot substitute for close observation of the constitution in action. And this, I want to suggest, was the most important factor for my "two Sirs" in their conversion to the case for a supreme law bill of rights. By then, they'd had time to dip a finger in and sample the broth. It was, they thought, a uniquely flavourless gruel. And they began to think about what could be added to spice it up.

me, then, contrast the experience of my own generation. First, for me, too, post-graduate study in the United States was a formative experience. But here's the thing. During my time in the United States, ${ }^{44}$ its Supreme Court had moved into an altogether different phase. The unwritten constitutional settlement that Ely and others had observed in the Court's post-1930s jurisprudence had fallen apart at the seams. During the 1990s and early 2000s, an activist-but-conservative Supreme Court had re-entered constitutional territory considered out of bounds since the 1930s and had used this re-found muscularity to strike down progressive federal legislation, for example, creating gun-free zones around schools ${ }^{45}$ providing a federal civil remedy for violence against women, ${ }^{46}$ and imposing monetary liability on states for age and disability discrimination. ${ }^{47}$

43 RQ Quentin-Baxter "Themes of constitutional development: the need for a favourable climate of discussion" (1985) 15 VUWLR 12 at 17-18.

44 I studied at Columbia University during the 2001-2002 academic year.

45 United States v Lopez 514 US 549 (1995).

46 United States v Morrison 529 US 598 (2000).

47 Kimel v Florida Board of Regents 528 US 62 (2000); and Board of Trustees of the University of Alabama $v$ Garrett 531 US 356 (2001). For a historically contextualised contemporaneous account of these developments, see Larry D Kramer "The Supreme Court 2000 Term - Foreword: We the Court" (2001) 115 Harv L Rev 4. 
Now I don't suggest these developments were directly applicable to New Zealand; indeed, the cases primarily concerned issues of federalism that have no parallel within New Zealand's unitary system of government. But even so, this turn of events was an unsettling reminder of the power of a supreme judiciary to abandon received understandings of the scope of its own authority and to remould the Constitution to its own image. And these developments also gave rise to a fresh wave of literature in the United States on the counter-majoritarian difficulty, and renewed interest in alternative modes of constitutionalism. ${ }^{48}$

What was more important, though, was that back home, the constitutional picture had also changed. First, there was the New Zealand Bill of Rights Act itself. The only real precedent for an "ordinary law" bill of rights of this kind was the Canadian Bill of Rights of 1960, and that had turned out to be pretty much a dead letter. So initial expectations for our Bill of Rights were low in some quarters. But almost from the first, some leading scholars saw transformative potential in the new Act. ${ }^{49}$ True, they said, it could not be used to strike down legislation. But after all, resort to this ultimate remedy was relatively rare in other jurisdictions. In other respects, our Bill of Rights ought to operate similarly to a supreme law one and its effect, they suggested, could well turn out to be profound.

Importantly, this transformative potential was also recognised early on by the Court of Appeal under the presidency of Robin Cooke - predominantly in the area of criminal procedure rights. ${ }^{50}$ And to top it off, other Commonwealth jurisdictions started to look to our Bill of Rights as a model

48 For example Mark Tushnet Taking the Constitution Away from the Courts (Princeton University Press, Princeton, 1999); Rachel E Barkow "More Supreme than Court? The Fall of the Political Question Doctrine and the Rise of Judicial Supremacy" (2002) 102 Colum L Rev 237; Kramer, above n 47; Larry D Kramer The People Themselves: Popular Constitutionalism and Judicial Review (Oxford University Press, New York, 2004). It is worth noting, too, that the "process theory" that had so appealed to the drafters of the New Zealand White Paper had, by then, been subject to a great deal of scholarly criticism. See, for example, Laurence H Tribe "The Puzzling Persistence of Process-Based Constitutional Theories" (1980) 89 Yale LJ 1063; Jeremy Waldron "A Rights-Based Critique of Constitutional Rights" (1993) 13 Oxford J Legal Studies 18.

49 For example PT Rishworth "The Potential of the New Zealand Bill of Rights" [1990] NZLJ 68; Janet McLean, Paul Rishworth and Michael Taggart "The Impact of the Bill of Rights on Administrative Law" in New Zealand Bill of Rights Act 1990: papers presented at seminars held by the Legal Research Foundation at Auckland on 24 August 1992 and Wellington on 25 August 1992 (Legal Research Foundation, Auckland, 1992) 62; JB Elkind "On the limited applicability of section 4, Bill of Rights Act" [1993] NZLJ 111; Paul Rishworth "Affirming the Fundamental Values of the Nation: How the Bill of Rights and the Human Rights Act Affect New Zealand Law" in Grant Huscroft and Paul Rishworth (eds) Rights and Freedoms: The New Zealand Bill of Rights Act 1990 and the Human Rights Act 1993 (Brookers, Wellington, 1995) 71. The sustained contribution made by scholar Paul Rishworth during this early period deserves special mention.

50 Key cases of the period included Ministry of Transport $v$ Noort [1992] 3 NZLR 260 (CA); $R v$ Te Kira [1993] 3 NZLR 257 (CA); Simpson v Attorney-General [1994] 3 NZLR 667 (CA) [Baigent's Case]; and Martin v Tauranga District Court [1995] 2 NZLR 419 (CA). 
for reform. Statutory bills of rights have since been adopted in the United Kingdom, the Australian state of Victoria and the Australian Capital Territory. And these reforms were accompanied by a wave of academic literature, conceptualising the statutory bill of rights model as a dynamic constitutional innovation that seeks to negotiate a middle path between the extremes of judicial and parliamentary supremacy. 51

Even on its own, then, this was a constitutional development worthy of careful study. But it was hardly an isolated reform. My two chefs had been busy in the kitchen. During the 1980s, so many new ingredients were added to the broth that Geoffrey Palmer was able to claim in his preface to the second edition of Unbridled Power that almost no aspect of New Zealand's system of government had been left untouched. ${ }^{52}$ And that was before the most important reform of all. The mixed member proportionality electoral system (MMP) transformed the New Zealand Parliament from one characterised by single-party majority governments into one characterised by minority and coalition governments. And by doing so, it loosened Cabinet's stranglehold over the legislative chamber. This was a fundamental change and one that had the potential to reverberate through New Zealand's entire system of government. And it came, as I said, at the end of a decade of change encompassing, for example, enhanced access to official information, significant changes to the way Parliament scrutinises legislation, greater parliamentary control over regulation-making, major reforms to the structure of the state sector and developments in relation to the status of the Treaty of Waitangi.

The point that I want to make here is a simple one. We needed to taste this revitalised constitutional soup; to get the measure of it. But we wouldn't really be able to assess the balance of flavours until the new ingredients had been heated and stirred in together; given time to dissolve and intermingle. We needed to take stock (if you'll excuse the pun) while the actors of the constitution adjusted to the new environs; and we needed to track the gradual impact of these changes on written and unwritten constitutional norms. This was not a process of days or weeks, but of years or even decades.

This moment of constitutional reconfiguration called, I believe, for a different kind of scholarship. Not for scholarship that sought to precipitate significant new constitutional change, but for scholarship that pursued two goals. On the one hand, to explore the theoretical potential of the changes that had been made; to provide normative guidance for constitutional actors on how they should behave in the new environment. And on the other hand (especially as the changes bedded in),

51 For example Stephen Gardbaum "The New Commonwealth Model of Constitutionalism" (2001) 49 Am J Comp L 707; F Klug "The Human Rights Act - A 'Third Way' or a 'Third Wave' Bill of Rights" [2001] EHRLR 361; Anthony Lester "The Magnetism of the Human Rights Act 1998" (2002) 33 VUWLR 53; George Williams "The Victorian Charter of Human Rights and Responsibilities: Origins and Scope" (2006) 30 MULR 880.

52 Geoffrey Palmer Unbridled Power: An Interpretation of New Zealand's Constitution and Government (2nd ed, Oxford University Press, Auckland, 1987) at preface. 
to track carefully how constitutional actors were actually responding. Scholarship, that is, that kept dipping a finger in and sampling the broth.

\section{TASTING THE CONSTITUTIONAL SOUP}

So far, so good. But the Bill of Rights is now approaching its quarter-century mark. And with MMP not far behind, it's fair to say the soup's now had some time to stew. So we ought to be in a position to reach some conclusions about what it tastes like. In an inaugural lecture, one is expected to provide an insight into one's own contribution to the field, so I hope it won't sound too pompous if I suggest that my work on the Bill of Rights has been directed at the second kind of scholarship, that is, I see myself as being in the soup-tasting kind of business. This is an ongoing task, and one that I have the opportunity to advance further through my recent Marsden grant. But let me give you some idea of what my taste buds have been detecting.

I want to preface this by saying that I've approached my soup tasting with a great deal of good will towards the New Zealand bill of rights model. I'm instinctively attracted, as many are, to the idea of an intermediate form of constitutionalism that mitigates the extremes of either parliamentary or judicial supremacy. Perhaps for that reason, it took me a while to notice a recurrent theme emerging from my soup-tasting endeavours. Across several pieces of research, examining the Act's performance in discrete areas of operation, I'd reached the same conclusion: that how the Act actually operated in practice often fell well short of the Platonic ideal sometimes described in the academic literature.

There's a tension in any constitutional system (but one that's particularly acute in New Zealand's unwritten constitution) between constitutional rhetoric and constitutional practice; between normative scholarship that offers a vision of how the constitution should operate, and descriptive scholarship that depicts the day-to-day experience of how it actually functions. Our constitution is both normative and descriptive - it says what should be and describes how things are. But these two functions can sometimes become blurred. When advancing normative claims about the constitution, it's tempting to overstate actual practice. And in a small jurisdiction such as ours, where significant appellate decisions are relatively infrequent, there's also a temptation to over-read those decisions when they do appear; to mistake passing remarks by an appellate court for the reality of constitutional practice, as reflected in the more routine activities of lower courts and tribunals. I think we sometimes do this with the Bill of Rights.

Let me give two examples relating to the Act's performance in the courts. The first concerns the circumstances in which the courts will express a view on whether legislation breaches the Bill of Rights. Everyone accepts that our Bill of Rights cannot be used to invalidate legislation. But if you read some of what's been written on this topic over the last decade or so, you could be forgiven for thinking that the New Zealand courts have recognised a formal (albeit non-binding) jurisdiction to declare legislative breaches of the Bill of Rights (or, at very least, that they've embraced a less formal role in routinely "indicating" in the course of their decisions when such inconsistencies 
occur) ${ }^{53}$ But my research suggests that neither of these things are true and that, in fact, the New Zealand courts go out of their way to avoid having to identify, let alone declare, legislative inconsistencies with the Bill of Rights. ${ }^{54}$

The second example concerns the role of the Bill of Rights in constraining administrative discretion, that is, discretion exercised by government officials. Early scholarship on the Bill of Rights assumed that, having first transformed the area of criminal procedure, the Bill of Rights would move on to reconfigure the field of administrative law. ${ }^{55}$ Most scholars now agree that this hasn't happened but, until recently, there was little careful analysis as to why. ${ }^{56}$ My own analysis of the case law suggests that a large part of the reason is the complete disjunction between the explanation given by scholars as to how the Bill of Rights is supposed to interact with administrative law, and what judges actually do in practice. Scholars have tended to assume that the Bill of Rights introduced a new standard of review to the field of administrative law: review to ensure that any limits placed on human rights by an exercise of official discretion are no more than is proportionate to the end achieved. But New Zealand judges are in fact profoundly resistant to proportionality review, and this leaves the actual role of the Bill of Rights in administrative law cases incoherent and largely unarticulated. ${ }^{57}$

If we turn to consider the impact of the Bill of Rights in the arena of Parliament, here, too, the Act has not lived up to some of the more optimistic claims that are made for it in the academic literature. For example, some eminent scholars have suggested that even though the courts can't invalidate legislation that breaches the Bill of Rights, nevertheless the Act is best understood as entailing a legal direction to Parliament itself not to enact laws that breach the Bill of Rights. It's for Parliament, they say, to self-enforce this obligation; but the obligation exists nevertheless. ${ }^{58}$ This is

53 For example Stephen Gardbaum The New Commonwealth Model of Constitutionalism: Theory and Practice (Cambridge University Press, Cambridge, 2013) at 146-147; Philip A Joseph Constitutional \& Administrative Law in New Zealand (3rd ed, Thomson Brookers, Wellington, 2007) at 1180 (though Joseph has pulled back from this suggestion in the new edition, launched shortly after this lecture was delivered: Philip A Joseph Constitutional \& Administrative Law in New Zealand (4th ed, Thomson Reuters, Wellington, 2014) at 1286).

54 Geiringer "On a Road to Nowhere", above n 12.

55 For example McLean, Rishworth and Taggart, above n 49.

56 But for some excellent recent contributions, see Janet McLean "The Impact of the Bill of Rights on Administrative Law Revisited: Rights, Utility, and Administration" [2008] NZ L Rev 377; and Hanna Wilberg "The Bill of Rights in Administrative Law Cases: Taking Stock and Suggesting some Reassessment" (2013) 25 NZULR 866.

57 Geiringer "Sources of Resistance", above n 12.

58 Paul Rishworth and others The New Zealand Bill of Rights (Oxford University Press, Melbourne, 2003) at 72; and Andrew Butler and Petra Butler The New Zealand Bill of Rights Act: a commentary (LexisNexis, Wellington, 2005) at 87-89. 
an appealing claim, but one that I doubt is legally correct and, in any event, is at odds with how those actors involved in the parliamentary process - the Speaker, the office of the Clerk, MPs themselves - understand the constitutional position. They think they are entitled to disregard the Bill of Rights; and as the courts have no power to contradict them, their view is surely what counts. ${ }^{59}$

I'm not convinced, either, by the related empirical claim that when Parliament enacts a Bill that has received a 7 report from the Attorney-General (a report advising, that is, that the Bill breaches the Bill of Rights), this generally reflects MPs' reasoned disagreement with the Attorney-General as to the scope of rights. ${ }^{60} \mathrm{My}$ more cynical conclusion is that MPs rarely engage in this kind of reasoning. ${ }^{61}$ And this accords with the view of Canadian political scientists Janet Hiebert and James Kelly, who have conducted a major but as yet unpublished study of the impact of the Bill of Rights on Parliament. In a recent speech, Hiebert said that the frequent s 7 reports to the New Zealand Parliament have had little effect on parliamentary deliberation. Parliament is simply not a venue, she said, that encourages independent moral judgements about the scope of rights. ${ }^{62}$

Well this places a premium on what happens before legislation is introduced to Parliament - on the quality of the advice that the Attorney-General receives in deciding whether to report on a Bill, and on the reluctance of governments to promote legislation that their law officer has advised them breaches the Bill of Rights. I've been involved in giving that advice to governments in both New Zealand and Victoria, and I share the view expressed by others that it's a valuable exercise that routinely results in improvements to the quality of legislation. But in the end, the statistics say it all. In the 23 and a half years since the Bill of Rights entered into force, New Zealand governments have chosen 31 times to introduce Bills to the House that their own Attorneys-General believed breached the Bill of Rights. And in only a small minority of cases were those human rights issues addressed as the Bill proceeded through the House. Even assuming Attorneys-General were overzealous in reporting on some of those occasions (and I can tell you, the incentives in government are far more towards under- than over-reporting) this is a sobering figure.

59 Geiringer "The Dead Hand of the Bill of Rights", above n 12.

60 See Janet McLean "The New Zealand Bill of Rights 1990 and Constitutional Propriety" (2013) 11 NZJPIL 19 at 34, citing Paul Rishworth "The Bill of Rights and 'Rights Dialogue' in New Zealand: After 20 Years, What Counts as Success?" (paper presented to University of Sydney Workshop on "Judicial Supremacy or Inter-Institutional Dialogue: Political Responses to Judicial Review", Sydney, May 2010).

61 See Geiringer "The Dead Hand of the Bill of Rights", above n 12, at 399. There are certainly few structural incentives to encourage MPs to engage with rights in this way - see Geiringer "The Dead Hand of the Bill of Rights", above n 12, at 400-401.

62 Janet Hiebert "Debating Compatibility in New Zealand and the United Kingdom: Has Legislative Behaviour Changed, or is it Business as Usual?" (New Zealand Centre for Human Rights Law, Policy and Practice "Parliament and the Protection of Human Rights - Pre-Legislative Scrutiny and the Role of s 7 of the Bill of Rights", Russell McVeagh, Wellington, March 2014). 
Standing back, then, a picture starts to emerge of a legal instrument that has never quite grown into the skin that some of the academic literature tried, valiantly, to clothe it in. I'm not suggesting that it's made no difference to our legal system; clearly it has. Nor that it didn't make more difference than some initially expected. If it's a matter for ongoing congratulation that our Bill of Rights proved more potent than the wet blanket of the Canadian Bill of Rights of 1960 then by all means, let's pat ourselves on the back. But I do want to suggest that the Bill of Rights hasn't lived up to the promise shown in some of those early criminal procedure decisions. And that, in many areas of operation, it hasn't had the transformative effect that some have hoped or claimed for it.

One matter that I think needs further scholarly attention is the interface between the Bill of Rights and MMP. Ultimately, the integrity of our statutory bill of rights model depends on its ability to place effective incentives on the political branches to engage, in good faith, with the human rights dimensions of legislative policy proposals. Why has the introduction of a proportionality-based electoral system not been more effective in supporting this kind of political activity? James Kelly has suggested that the orientation of MMP politics towards backroom deals may in fact reduce the possibilities for parliamentary engagement over bill of rights issues. ${ }^{63}$ But that begs the question, surely, as to what sort of impact those backroom negotiations are having on human rights issues. There is an analogy here with the work that Elizabeth McLeay, Polly Higbee and I did on the use of urgency in the New Zealand Parliament. ${ }^{64}$ We found that the need for major parties operating in the MMP Parliament to negotiate support for their urgency motions had operated as a significant constraint on the use of urgency. But we also found that this constraint was uneven; that it was sometimes weak or even absent and that there was a complex range of factors influencing whether or not minor parties gave or withheld their support on particular occasions.

It's certainly the case that some post-MMP governments have been more willing or able than others to enact legislation that has breached the Bill of Rights, and I suspect close study would identify a similar range of factors (beyond the obvious one of party ideology) that explain why that is so. What's clear, though, is that here, too, the structural constraint imposed by MMP has been uneven at best. Bearing in mind the high proportion of $\mathrm{s} 7$ reports that have related to criminal justice issues, we should also recall Nicola Lacey's sobering research on penal populism. She demonstrated that whereas proportionality-based electoral systems are generally more resistant to penal populism than plurality-based systems, New Zealand is the exception that proves the rule. And she suggested that because MMP was layered on top of a pre-existing liberal market economy

63 James B Kelly "Judicial and political review as limited insurance: the functioning of the New Zealand Bill of Rights Act in 'hard' cases" (2011) 49 Commonwealth \& Comparative Politics 295 at 309-310.

64 Claudia Geiringer, Polly Higbee and Elizabeth McLeay What's the Hurry? Urgency in the New Zealand Legislative Process 1987-2010 (Victoria University Press, Wellington, 2011). 
and a highly adversarial political tradition, it may be proving resistant to the consensus-oriented style of politics that is traditionally associated with proportional representation. ${ }^{65}$

Time is getting short and I can feel my Mr Bulwark shifting impatiently in his seat. So let me come right out and say it. I admit it, Mr Bulwark. You were right all along. The wall's not high enough; the soup's still too thin; the caravan needs a new suspension; the brick-of-sponge is letting the water in. Our constitutional soup needs more thickening, and it's time we started to focus more intently again on how what we're going to do about.

And another thing I'm increasingly coming around to your way of thinking on: if we were to give more power to judges, the sky wouldn't fall in. I don't think this is the only way to thicken up the constitution; or even that it would be sufficient. Our democratic institutions are in need of attention too. But I think it's a serious option that we need to reconsider.

It would take at least another hour even to begin to justify this assertion, so let me just say two things. The first is that the question of how to divide up power within our constitution is a highly situated one that cannot ultimately be resolved by the kind of generalised philosophical theorising engaged in, for example, by the likes of New Zealand ex-pat Jeremy Waldron. ${ }^{66}$ His is doubtless one of the most elegant and persuasive contemporary statements of the counter-majoritarian difficulty. ${ }^{67}$ But it is based on a somewhat idealised version of a functioning democracy that - as even his own writings now acknowledge - bears little resemblance to New Zealand's constitutional reality. ${ }^{68}$

Secondly, in thinking about the question of judicial power, we've been fixated on the American experience for too long. The problems of a large federal state are not ours. Our puzzle remains how to avoid the over-concentration of power in a highly centralised system of responsible government operating still, despite MMP, within the basic paradigm of Westminster constitutionalism.

And that, of course, is what Mr Bulwark has been trying to tell us all along.

65 Nicola Lacey "The Prisoners' Dilemma and Political Systems: The Impact of Proportional Representation on Criminal Justice in New Zealand" (2011) 42 VUWLR 615; and Nicola Lacey "Political Systems and Criminal Justice: The Prisoners' Dilemma after the Coalition" (2012) 65 CLP 203.

66 Waldron acknowledges the situated nature of the question himself in Waldron, above $\mathrm{n} 17$.

67 For example Waldron, above n 48; Jeremy Waldron Law and Disagreement (Clarendon Press, Oxford, 1999); and Waldron, above n 17.

68 Jeremy Waldron "Compared to what? Judicial activism and New Zealand's Parliament" [2005] NZLJ 441. See also Jeremy Waldron "Parliamentary Recklessness: Why we need to legislate more carefully" (Maxim Institute Annual John Graham Lecture, Auckland, July 2008). 